University of Nebraska - Lincoln

DigitalCommons@University of Nebraska - Lincoln

USDA National Wildlife Research Center - Staff Publications
U.S. Department of Agriculture: Animal and Plant Health Inspection Service

January 1970

\title{
WINTER BEHAVIOR OF THE EASTERN BOX TURTLE, TERRAPENE C. CAROLINA L., IN EASTERN TENNESSEE
}

Richard A. Dolbeer

usa

Follow this and additional works at: https://digitalcommons.unl.edu/icwdm_usdanwrc

Part of the Environmental Sciences Commons

Dolbeer, Richard A., "WINTER BEHAVIOR OF THE EASTERN BOX TURTLE, TERRAPENE C. CAROLINA L., IN EASTERN TENNESSEE" (1970). USDA National Wildlife Research Center - Staff Publications. 160.

https://digitalcommons.unl.edu/icwdm_usdanwrc/160

This Article is brought to you for free and open access by the U.S. Department of Agriculture: Animal and Plant Health Inspection Service at DigitalCommons@University of Nebraska - Lincoln. It has been accepted for inclusion in USDA National Wildlife Research Center - Staff Publications by an authorized administrator of DigitalCommons@University of Nebraska - Lincoln. 
ping turtle, Chelydra serpentina. Ibid. 166: $491-498$.

eggs of the commonservations on females and serpentina. Am. Midl. Nat. 84:69-76.

C. L. Yntema, Department of Anatomy, $U p$ state Medical Center, Syracuse, New York 13210 .

WINTER BEHAVIOR OF THE EASTERN BOX TURTLE, TERRAPENE C. CAROLINA L., IN EASTERN TENNESSEE.-A field study of winter movements and depths and types of hibernacula of the eastern box turtle, Terrapene carolina carolina L., was undertaken from October 1968-January 1969.

The study was confined to 23 acres $(9.2$ hectares) within the University of Tennessee's Cherokee Woodlot, located $1.6 \mathrm{~km}$ south of Knoxville, Tennessee. The area consists of densely wooded hills in which a remnant of the original forest remains (Shanks and Norris, 1950). Trees are primarily deciduous with oaks (Quercus spp.) being the most common species. Shrub, sapling and vine density is high over much of the area providing a dense undercover. The elevation ranges from 280 to 350 meters.

Trailing devices (Stickel, 1950) were used to study winter movements and to follow turtles to their hibernacula. Trailed turtles were checked daily with the path and distance of movement recorded. In addition, depths and types of hibernacula were recorded whenever the turtles burrowed into the leaf litter and became inactive.

Maximum and minimum daily soil temperatures were recorded at a depth of $10 \mathrm{~cm}$ $(3.8 \mathrm{~cm}$ of leaf litter, $6.2 \mathrm{~cm}$ of soil) on an east facing slope in the area of activity of two trailed turtles. Daily air and precipitation data were obtained from a U.S. Weather Bureau station, $11.2 \mathrm{~km}$ from the study area.

Trailing devices were attached to 11 turtles between 10 and 21 October. Six of these turtles were lost by 22 October so only five turtles were trailed throughout the complete period (until 31 January).

From 10 to 21 October, daily movements of at least two, and usually all, of the trailed turtles occurred. After 22 October, the first day of no movements, the daily movements varied considerably. Table 1 shows the record of movements for the five turtles trailed from 21 October through 31 January. During this 103-day period, 43 individual movements
Table 1. Distances (in meters) of Turtle (Terrapene c. carolina) Movements (21 October31 January).

\begin{tabular}{|c|c|c|c|c|c|}
\hline \multirow[b]{2}{*}{ Date } & \multicolumn{5}{|c|}{ Turtles } \\
\hline & 8 & 16 & 54 & 56 & 169 \\
\hline $21 \mathrm{Oct}$ & 1.5 & 0 & 0 & 0 & 0 \\
\hline 23 & 0 & 0 & 0 & 3.7 & 1.5 \\
\hline 25 & 1.5 & 0 & 0 & 0 & 0 \\
\hline 28 & $-^{1}$ & 0 & 0 & 1.5 & 0 \\
\hline 1 Nov & - & 0 & 6.1 & 0 & 7.6 \\
\hline 2 & - & 0 & 3.0 & 22.9 & 0 \\
\hline 3 & - & 0 & 0 & 0 & 7.6 \\
\hline 4 & - & 7.6 & 1.5 & 69.7 & 12.2 \\
\hline 5 & - & 0 & 0 & 0 & 1.5 \\
\hline 8 & - & 0 & .6 & 0 & 0 \\
\hline 10 & - & 0 & .6 & 0 & 6.1 \\
\hline 16 & - & 27.4 & 9.1 & 0 & 42.7 \\
\hline 17 & - & 33.5 & 0 & 24.4 & 45.8 \\
\hline 22 & 30.5 & 6.1 & 0 & 0 & 0 \\
\hline 23 & 122.3 & 15.2 & 0 & 0 & 10.7 \\
\hline 25 & 18.3 & 24.3 & 0 & 15.2 & 4.6 \\
\hline 1 Dec & 30.5 & 3.0 & 42.7 & 36.6 & 0 \\
\hline 3 & 15.2 & 0 & 0 & 0 & 0 \\
\hline 6 & 12.2 & 0 & 0 & 0 & 0 \\
\hline 13 & 12.2 & 0 & 4.6 & 0 & 0 \\
\hline 24 Jan & 0 & 0 & 0 & 27.4 & 12.2 \\
\hline
\end{tabular}

${ }^{1}$ Lost on 28 October and found on 21 November.

were recorded on 21 different days. Movements were common until 13 December after which no movements were recorded until 24 January.

The relationship between temperature, precipitation and movements was examined. Two trends were apparent. The first was that movements were more common on warmer days. While only 29 of the 103 days $(28 \%)$ had a maximum temperature of above $16^{\circ} \mathrm{C}, 32$ of the 43 movements $(74 \%)$ occurred on these days. The other 11 movements occurred on days in which the maximum temperature ranged between 7 and $14^{\circ} \mathrm{C}$. The second trend was that movements were closely related to rainfall during December and January; nine of the ten movements recorded in these months occurred on the day of or following a rainfall of $6.5 \mathrm{~mm}$ or more. Such a relationship was not found in October and November as only 15 of the 33 movements occurred on days of or following a rainfall of any amount. This indicates that rainfall may have a much greater influence on movements during the colder part of the winter. The daily maxi- 

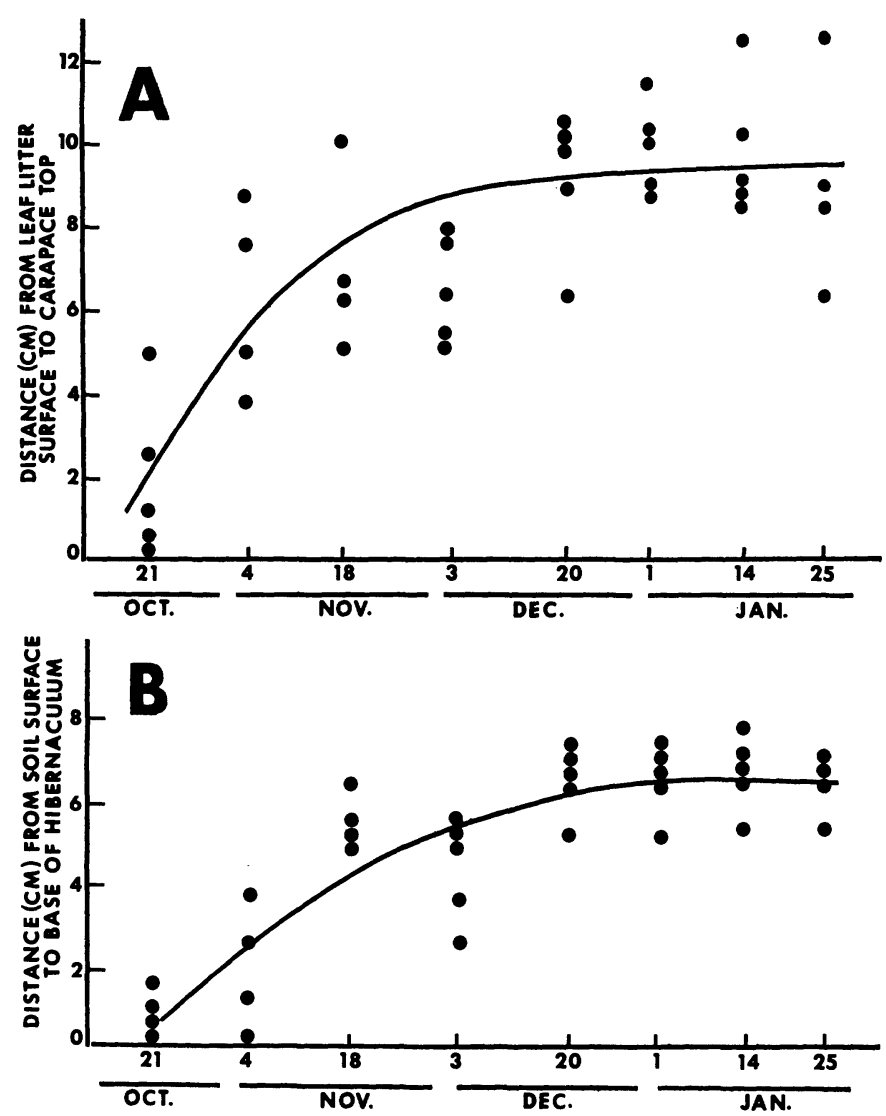

Fig. 1. Depths of hibernacula for eastern box turtles. A, Distance from leaf litter surface to carapace top; B, Distance from soil surface to base of hibernacula. Lines fitted by eye.

mum temperature averaged $6.1^{\circ} \mathrm{C}$ lower for December and January as compared to 21 October-30 November.

Whenever the turtles were not active, they were burrowed under the leaf litter. Periodically, measurements were made of depths to which the turtles burrowed (Fig. 1). Hibernacula depths increased until midDecember and leveled off at an average depth of $15.5 \mathrm{~cm}$ (9.7 leaf litter, 5.8 soil). The turtles usually shaped out a cavity in the soil so that the top of the carapace was even with the soil surface. This depth was adequate to insulate the turtles from the coldest temperatures through 31 January. The minimum recorded soil temperature at $10.0 \mathrm{~cm}$ (3.8 leaf litter, 6.2 soil) was $1.1^{\circ} \mathrm{C}$. This recording was taken within $7 \mathrm{~m}$ of two turtle hibernacula. The maximum depth reached by any turtle was $19.0 \mathrm{~cm}$ (12.7 leaf litter, 6.3 soil).
The types of hibernacula varied with the season. In late fall, the turtles sometimes burrowed under leaf litter in open sites, but more often chose places where leaf litter had built up, such as next to fallen logs, stumps or rocks. In colder weather, the turtles preferred stump holes; four of the five turtles spent 13 December-24 January in, or next to, stump holes. These depressions contained a thick mat of leaf litter and the soil was mixed with rotting wood.

Previous studies have shown that winter movements are not uncommon for the box turtle. Carpenter (1957) studied the hibernation of the three-toed box turtle, Terrapene c. triunguis, in Oklahoma, and found that turtles were often active during fall and early winter. Cahn (1933) reported that 24 eastern box turtles in an enclosed pen in Illinois went into hibernation in late November after a three-week period of alter- 
nating burrowing and active movement. $\mathrm{He}$ also noted that two turtles moved about the pen for one day in January. Allard (1948) reported finding turtles active during all months of winter.

Only scattered observations have been previously made on box turtle hibernacula. Carpenter (1957) reported that the average hibernacula depth of the three-toed box turthe was $13.5 \mathrm{~cm}$ (7.1 leaf litter, 6.4 soil). In his study, $39 \%$ of the hibernacula were located in decaying stump holes. Minton (1944) reported that an eastern box turtle hibernated at a maximum depth of $12.7 \mathrm{~cm}$ during one winter in Illinois. In Great Smoky Mountains National Park, an eastern box turtle was discovered in mid-winter hibernating under a brush pile with its carapace top even with the soil surface (Huheey and Stupka, 1967:46).

In conclusion, eastern box turtles select areas with a thick mat of leaf litter, rotting wood or brush for hibernacula sites. The depths and types of hibernacula are similar to those of the three-toed box turtle. Winter movements are more common on warmer days. Rainfall appears to be an important stimulus for movements during December and January.

Appreciation is extended to James $T$. Tanner for reviewing the manuscript.

\section{Literature Cited}

Allakd, H. A. 1948. The eastern box turtle and its behavior. J. Tenn. Acad. Sci. 28:307321.

CAHN, A. R. 1933. Hibernation of the box turtle. Copeia 1933(1):13-14.

CARPENTER, C. C. 1957. Hibernation, hibernacula and associated behavior of the threetoed box turtle (Terrapene carolina triunguis). Copeia 1957(4):278-282.

HuheEy, J. E., ANd A. Stupka. 1967. Amphibians and reptiles of Great Smoky Mountains National Park. Univ. of Tenn. Press, Knoxville, Tenn.

Minton, S. 1944. Introductions to the study of reptiles of Indiana. Am. Midl. Nat. 32(2): 438-477.

Shanks, R. E., AND F. H. NorRIs. 1950. Microclimatic variation in a small valley in eastern Tennessee. Ecology 31:532-539.

Stickel, L. F. 1950. Populations and home range relations of the box turtle, Terrapene $c$. carolina (Linnaeus). Ecol. Monogr. 20:351378.

Richard A. Dolbeer, Colorado Cooperative Wildlife Research Unit, Colorado State University, Fort Collins, Colorado 80521.
RADIOTELEMETRIC OBSERVATIONS OF CARDIAC RATES IN THE ORNATE BOX TURTLE.-A pulse-modulated radio transmitter, a single pulse triggered by each QRS spike of the animal's electrocardiogram, was used to monitor the cardiac activity of an adult male ornate box turtle, Terrapene ornata ornata, moving about in nature with considerable freedom of movement. These observations extended from 26 August to 26 September 1966.

The electrocardiogram signal was monitored via silver wire electrodes introduced through small holes drilled in the carapace. This signal, after amplification, triggered a pulse circuit which turned on the transmitter, once for each beat of the heart. The weight of the apparatus was about $35 \mathrm{~g}$, or about $10 \%$ of the body weight.

As an example of the types of observations such a system makes possible, Fig. 1 shows the time course of the cardiac rate, in beats per minute, during a morning period of basking. The rate observations were begun from a vantage point out of sight of the turtle. An increasing cardiac rate suggested that the animal was basking and this was visually confirmed by unobtrusive observation. The turtle remained nearly motionless during the entire time indicated, with only an occasional head movement. At the time indicated on the figure the turtle abruptly left the spot where he had remained for over an hour and moved into shade nearby. There followed a slight slowing of the heart, after a maximum rate of 48 beats per min had been reached.

Fig. 2 summarizes one month's observations on the effect of temperature on cardiac rate. The temperature measurements represent ambient air temperature at ground level in the immediate vicinity of the turtle. Observations were included only in cases where equilibrium conditions seemed to pertain (in the shade with the cardiac rate reasonably constant over an interval of several minutes). Under these conditions it was assumed that the turtle's body temperature would closely reflect that of the surrounding air.

Data relating turtle cardiac rate and temperature are meager, and that which does exist has been taken under laboratory, rather than field, conditions. Akers and Damm (1963) exposed Graptemys geographica and Pseudemys scripta elegans to infrared heating lamps while temperatures were taken with 